\title{
Penerapan Penggunaan Telegram dalam Pembelajaran Bahasa Indonesia Meningkatkan Kemampuan dan Hasil Belajar pada Teks Hikayat
}

\author{
Evi Barokah
}

SMKN 1 Rembang Kabupaten Purbalingga, Indonesia

Email : evibarokah35@guru.smk.belajar.id

\begin{abstract}
Abstrak: Penelitian ini bertujuan untuk 1) Mengetahui pemanfaatan aplikasi Telegram dalam Pembelajaran Bahasa Indonesia, 2) Mengetahui proses pelaksanaan pembelajaran dalam meningkatan pemahaman peserta didik kelas X SMK Negeri 1 Rembang dalam mengidentifikasi nilai-nilai yang terkandung dalam teks cerita rakyat (hikayat), 3) Peningkatan kemapuan mengidentifikasi nilai-nilai yang terkandung dalam teks hikayat peserta didik kelas X SMKN 1 Rembang Kabupaten Purbalingga setelah mengikuti pembelajaran dengan model Contextual Teaching and Learning (CTL), 4) Peningkatan hasil belajar peserta didik kelas X SMK Negeri 1 Rembang setelah mengikuti pembelajaran dengan model Contextual Teaching and Learning (CTL). Adapun metode yang digunakan di dalam penelitian ini adalah metode kualitatif deskriptif. Subjek penelitian ini adalah peserta didik SMK Negeri 1 Rembang Kelas X Rekayasa Perangkat Lunak 1. tersebut tersebut terdiri dari 29 peserta didik, yaitu 8 laki-laki dan 21 perempuan. Penelitian ini dilakukan dengan 3 Siklus, Meliputi perencanaan (planning), pelaksanaan (acting), pengamatan (observing) dilakukan dalam proses pembelajaran yaitu melihat situasi kegiatan belajar, dan penilaian (evaluating) pembelajaran serta refleksi (reflecting). Dalam pembelajaran Bahasa Indonesia di SMKN 1 Rembang Purbalingga pertama kalinya memanfaatkan aplikasi Telegram untuk kegiatan pembelajaran berbasis online, tetapi penggunaan aplikasi telegram dalam media pembelajaran jarak jauh dinilai kurang efektif daripada pembelajaran secara offline atau tatap muka. Hal ini disebabkan karena kebutuhan kuota yang harus selalu tersedia dan jaringan yang stabil, motivasi belajar siswa yang menurun sehingga tidak ada jaminan apakah siswa benar-benar mengikuti kegiatan belajar mengajar. Tetapi, disamping itu juga terdapat beberapa keuntungan dari pembelajaran online menggunakan telegram. Seperti siswa yang sebelumnya kurang aktif menjadi lebih aktif, waktu dan tempat yang digunakan lebih fleksibel, dan memberikan pengalaman belajar yang lebih banyak mengenai pemanfaatan aplikasi online.
\end{abstract}

Kata kunci: Telegram, Teks Hikayat, Contextual Teaching and Learning (CTL)

Absrtract : This study aims to 1) Knowing the use of the Telegram application in Indonesian Language Learning, 2) Knowing the process of implementing learning in improving the understanding of class $X$ students of SMK Negeri 1 Rembang in identifying the values contained in folklore texts (saga), 3) Increasing the ability to identify the values contained in the saga text of class $X$ students of SMKN 1 Rembang, Purbalingga Regency after participating in learning with the Contextual Teaching and Learning (CTL) model, 4) Improved learning outcomes of class X students of SMK Negeri 1 Rembang after participating in learning with the model Contextual Teaching and Learning (CTL). The method used in this research is descriptive qualitative method. The subjects of this study were students of SMK Negeri 1 Rembang Class X Software Engineering 1. The students consisted of 29 students, namely 8 males and 21 females. This research was conducted in 3 cycles, including planning (planning), implementation (acting), observing (observing) carried out in the learning process, namely seeing the 
situation of learning activities, and evaluating learning and reflecting. In learning Indonesian at SMKN 1 Rembang Purbalingga for the first time using the Telegram application for online-based learning activities, but the use of the telegram application in distance learning media was considered less effective than offline or face-to-face learning. This is due to the need for quotas that must always be available and a stable network, students' learning motivation has decreased so there is no guarantee whether students actually participate in teaching and learning activities. However, besides that, there are also several advantages of online learning using Telegram. As students who were previously less active become more active, the time and place used is more flexible, and provides a more learning experience regarding the use of online applications.

Keywords : Telegram, Saga Tex,; Contextual Teaching and Learning (CTL)

Copyright (c) 2021 The Authors. This is an open access article under the CC BY-SA 4.0 license (https://creativecommons.org/licenses/by-sa/4.0/)

\section{PENDAHULUAN}

Pandemi corona virus disease 2019 (COVID-19) pertama kali ditemukan pada akhir tahun 2019 di Kota Wuhan, Provinsi Hubei, China. Organisasi Kesehatan Dunia (WHO) yang berada di China memperoleh pemberitahuan tentang adanya sejenis penyakit yang mirip dengan Pneumonia, yaitu salah satu penyakit infeksi pernapasan akut yang menyerang paru-paru, akan tetapi penyebabnya belum diketahui secara pasti. Berdasarkan informasi dari pihak berwenang, pasien yang terinfeksi COVID- 19 merupakan pedagang yang bekerja di pasar ikan Huanan.

Setelah diteliti dan ditelusuri lebih lanjut, Penyakit Coronavirus (COVID19) adalah penyakit menular yang disebabkan oleh virus baru yang disebut dengan novel corona virus masih terkait dengan keluarga virus yang sama dengan Severe AcuteRespiratory Syndrome (SARS) dan beberapa jenis flu biasa.

Berawal dari kasus lokal, COVID-19 menyebar ke seluruh dunia. Penularan virus COVID-19 terjadi melalui cairan atau droplets berasal dari batuk, bersin, dan kontak langsung dengan orang yang terinfeksi virus COVID-19 ataupun saat menyentuh mukosa mata dan hidung, setelah menyentuh benda atau permukaan yang terdapat virus. COVID-19 pertama dilaporkan di Indonesia tanggal 2 Maret 2020 sejumlah dua kasus. Data 31 Maret 2020 menunjukkan kasus yang terkonfirmasi berjumlah 1.528 kasus dan 136 kasus kematian dengan tingkat mortalitas sebesar 8,9\% yang merupakan tertinggi di Asia Tenggara. Oleh sebab itu, Virus corona COVID-19 ditetapkan sebagai pandemi oleh Organisasi 
Kesehatan Dunia (WHO) dan seluruh masyarakat disarankan untuk tetap tinggal di rumah dan menjaga jarak fisik dengan orang lain selama kondisi pandemi.

Akibatnya, seluruh aktivitas sosial yang biasanya berjalan normal, menjadi terhenti. Sebagian besar perusahaan dan sarana pendidikan mulai beradaptasi dengan memperkerjakan karyawannya dari rumah (work from home) dan membuat sistem belajar online untuk siswa dan mahasiswa. Sebab adanya kemajuan teknologi pada masa sekarang ini seluruh kegiatan dapat dilaksanakan secara online. Ada berbagai macam media pembelajaran yang dapat menunjang atau membantu kegiatan bekerja dan belajar online salah satunya adalah aplikasi Telegram.

Telegram adalah salah satu aplikasi chatting yang didukung oleh berbagai tools dan fitur canggih sehingga membuat telegram menjadi semakin digemari. Salah satu fitur yang bisa digunakan dalam pembelajaran adalah telegram bot. Telegram bot adalah sebuah bot atau robot yang diprogram dengan berbagai perintah untuk menjalankan serangkaian instruksi yang diberikan oleh pengguna yang dioperasikan oleh perangkat lunak yang memiliki fitur AI (Ariskisaputri, 2019).

Disamping itu, pada kondisi pandemi, semakin banyak orang yang mulai memanfaatkan aplikasi telegram untuk bekerja atau belajar dari rumah. Oleh sebab itu, saat ini telegram menjadi salah satu aplikasi yang mengalami pertumbuhan tercepat. Angka pengguna harian aplikasi telegram meningkat hingga 25 kali lipat pada periode antara bulan Januari hingga Juli 2021. Telegram merupakan versi yang terbaru dan lebih kuat dibandingkan dengan aplikasi lainnya. Telegram memiliki fitur yang mampu ditampilkan pada aplikasi dekstop, web, Android, dan IOS. Selain itu, aplikasi telegram memiliki Interface atau antarmuka yang unik dan fungsional dengan ukuran ringan dan cepat, mengedepankan pengelolaan yang lebih efisien sehingga mudah untuk digunakan dan diikuti oleh semua penggunanya.

Telegram dapat digunakan sebagai salah satu media pembelajaran yang dapat menunjang proses pembelajaran siswa dari rumah sekaligus mengajarkan siswa untuk memanfaatkan teknologi sejak dini sehingga dapat memberikan pengalaman yang bermakna untuk siswa tersebut. Pemanfaatan telegram sebagai 
media pembelajaran bertujuan untuk mengetahui proses pelaksanaan pembelajaran dalam meningkatkan pemahaman peserta didik kelas X SMK Negeri 1 Rembang dalam mengidentifikasi nilai-nilai yang terkandung dalam teks cerita rakyat (hikayat), meningkatan kemapuan mengidentifikasi nilai-nilai yang terkandung dalam teks hikayat. Peningkatan hasil belajar peserta didik kelas X SMK Negeri 1 Rembang setelah mengikuti pembelajaran dengan model Contextual Teaching and Learning (CTL) dengan menggunakan aplikasi telegram sebagai media pembelajaran.

Sastra merupakan salah satu materi pembelajaran yang harus disampaikan pada pembelajaran Bahasa Indonesia. Pembelajaran sastra termasuk dalam pengajaran yang sudah lama dan sampai sekarang tetap bertahan serta tercantum dalam kurikulum sekolah. Bertahannya pembelajaran sastra di sekolah dikarenakan sastra mempunyai peranan yang sangat penting dalam mencapai aspek tujuan pendidikan, seperti aspek pendidikan susila, sosial, sikap, penilaian, dan keagamaan.

Salah satu upaya dalam mencapai tujuan pengajaran sastra, pengetahuan sastra yang diajarkan pada peserta didik hendaknya berangkat dari suatu penghayatan atas suatu karya sastra yang konkrit. Hal ini berarti bahwa pengetahuan ini merupakan pelengkap pengalaman sastra sehingga peserta didik benar-benar memperoleh akar yang kuat.

Sehubungan dengan hal tersebut maka nilai pengajaran sastra memiliki dua tuntutan yang dapat diungkapkan sehubungan dengan watak, yaitu (a) pengajaran sastra hendaknya mampu membina perasaan yang lebih tajam, dan (b) pengajaran sastra hendaknya mampu memberikan bantuan dalam usaha menngembangkan kualitas kepribadian peserta didik, misalnya ketekunan, kepandaian, pengimajian, dan penciptaan.

Dalam pembelajaran sastra khususnya cerita rakyat (hikayat), peserta didik diharapkan dapat mengidentifikasi nilai-nilai yang terkandung dalam teks cerita rakyat (hikayat). Selain itu, dengan mengidentifikasi nilai-nilai yang terkandung dalam teks cerita rakyat (hikayat) pengalaman batin peserta didik akan bertambah, wawasan peserta didik semakin luas sehingga terbentuk sikap posistif dalam diri peserta didik untuk menerapkan norma-norma yang berlaku dimasyarakat. 
Dalam mengidentifikasi nilai-nilai yang terkandung dalam teks cerita rakyat (hikayat), sering ditemukan beberapa permasalahan diantaranya sebagian besar peserta didik kelas X SMKN 1 Rembang Purbalingga yang beranggapan pelajaran Bahasa dan Sastra Indonesia adalah pelajaran yang membosankan dan menjenuhkan, peserta didik kelas X SMKN 1 Rembang Purbalingga menganggap pelajaran sastra khususnya mengidentifikiasi nilai-nilai yang terkandung dalam teks cerita rakyat (hikayat) sulit diikuti, kurangnya pemahaman peseta didik kelas X SMK Negeri Karanganyar terhadap materi sastra khususnya mengidentifikasi nilai-nilai yang terkandung dalam teks cerita rakyat (hikayat), strategi belajar dan mengajar sastra khususnya teks cerita rakyat (hikayat) yang digunakan guru kurang optimal.

Untuk mengatasi permasalahan tersebut, maka guru harus memilih strategi pembelajaran yang tepat. Salah satu strategi pembelajaran yang tepat menurut peneliti adalah pembelajaran dengan menggunakan model contextual teaching and learning (CTL). Pembeajaran dengan model contextual teaching and learning (CTL) tersebut diharapkan dapat meningkatkan kemampuan mengidentifikasi nilai-nilai yang terkandung dalam teks cerita rakyat (hikayat) peserta didik dan mengubah perilaku peserta didik ke arah yang lebih baik.

Penggunaan model contextual teaching and learning (CTL) tersebut diharapkan peserta didik dapat lebih aktif dan berminat dalam pembelajaran sastra khususnya mengidentifikasi nilai-nilai yang terkandung dalam teks cerita rakyat (hikayat). Penelitian ini bertujuan untuk mengetahui bagaimana pemanfaatan telegram dalam pembelajaran untuk meningkatan pemahaman peserta didik kelas X SMK Negeri 1 Rembang dalam mengidentifikasi nilai-nilai yang terkandung dalam teks cerita rakyat (hikayat), meningkatan kemapuan mengidentifikasi nilainilai yang terkandung dalam teks hikayat, Peningkatan hasil belajar peserta didik kelas X SMK Negeri 1 Rembang setelah mengikuti pembelajaran dengan model contextual teaching and learning (CTL) pada masa pandemi COVID-19 di SMKN 1 Rembang Purbalingga.

Terdapat satu penelitian yang mengkaji mengenai nilai-nilai dalam unsur ekstrinsik..Penelitian itu dilakukan oleh Putu Sri Indra Wahyuni (2020) mengkaji mengenai nilai sosial dalam cerpen 'titik dikala senja' dalam antalogi cerpen 
penjara. Walaupun membahas hal yang sama mengenai nilai-nilai yang ada dalam unsur ekstrinsik oleh Putu Sri Indra Wahyuni hanya mengambil salah satu yaitu mengenai nilai sosial. Sedangkan penelitian ini membahas mengenai penerapan penggunaan media belajar telegram dalam teks hikayat di SMKN 1 Rembang Purbalingga. Sehingga penelitian ini dapat digunakan di masa depan demi mencapai fleksibilitas pendidikan tanpa mengurangi ilmu atau pembelajaran yang dilaksanakan.

\section{METODE}

Subjek penelitian ini adalah kemampuan mengidentifikasi nilai-nilai yang terkandung dalam teks cerita rakyat (hikayat) peserta didik SMK Negeri 1 Rembang Kelas X rekayasa perangkat lunak 1. Kelas tersebut terdiri dari 29 peserta didik, yaitu 8 laki-laki dan 21 perempuan. Peneliti mengambil subjek tersebut dengan alasan berdasarkan hasil pembelajaran, saat ini kondisi kemampuan mengidentifikasi nilai-nilai yang terkandung dalam teks cerita rakyat (hikayat) peserta didik kelas tersebut rendah.

Penelitian ini dilakukan dengan menggunakan pre test-post dengan menggunakan tiga siklus. Siklus I Meliputi perencanaan (planning), pelaksanaan (acting), pengamatan (observing) dilakukan dalam proses pembelajaran yaitu melihat situasi kegiatan belajar dan penilaian (evaluating) pembelajaran serta refleksi (reflecting), melihat perkembangan peningkatan kemapuan mengidentifikasi nilai-nilai yang terkandung dalam teks cerita rakyat (hikayat) peserta didik. Siklus II Meliputi perencanaan (planning) berdasarkan refleksi Siklus I, pelaksanaan (acting), pengamatan (observing) dilakukan dalam proses pembelajaran yaitu melihat situasi kegiatan belajar dan evaluasi proses serta refleksi (reflecting), melihat persentase peningkatan kemapuan mengidentifikasi nilai-nilai yang terkandung dalam teks cerita rakyat (hikayat) peserta didik.

\section{HASIL DAN PEMBAHASAN}

Penerapan penggunaan telegram dalam pembelajaran Bahasa Indonesia pada teks hikayat di SMKN 1 Rembang Purbalingga. Sebelum adanya COVID-19, kegiatan pembelajaran berjalan secara konvensional khususnya di SMKN 1 Rembang Purbalingga. Guru dan siswa lebih sering melakukan kegiatan 
pembelajaran secara tatap muka atau bertemu secara langsung. Namun semenjak diberlakukannya sosial distancing, kebijakan sekolah menyatakan bahwa seluruh kegiatan pembelajaran dilaksanakan berbasis online atau e-learning. Dimana kebanyakan sekolah yang ada di Indonesia menggunakan aplikasi telegram sebagai media untuk pembelajaran.

Aplikasi telegram memberikan fasilitas dimana pembelajaran bahasa Indonesia akan menggunakan model synchronous dalam aplikasi telegram bisa menggunakan fitur obrolan suara guru sebagai partisipan dapat melakukan share screen yang berarti dapat mengubah layar utama menjadi file yang dibutuhkan untuk kepentingan pembelajaran. Guru dapat mempersentasikan power point yang ingin ditampilkan dan dijelaskan kepada siswa dan guru juga bisa membagikan video yang ingin ditampilkan dan siswa bisa menyimak video yang dibagiakan oleh gurunya melalui telegram. Dapat dikatakan seperti pembelajaran di kelas yang biasanya dilakukan guru dengan menggunakan bantuan bahan ajar seperti slide power point yang memudahkan peserta didik dalam memahami materi yang disampaikan. hal tersebut sangat memberikan keuntungan bagi guru-guru maupun peserta didik.

Selain synchronous juga ada model ansynchronous yaitu model yang tidak mengharapkan kehadiran guru dalam belajar siswa atau dengan kata lain siswa mandiri dalam belajarnya. Model ini juga sering digunakan dalam pembelajaran bahasa Indonesia. Guru hanya membagikan vidio pembelajaran, link, atau file yang berisi penjelasan mengenai materi yang akan diajarkan dengan ukuran maksimum 1.5 GB per file. Telegram memiliki ruang penyimpanan tersendiri bernama cloud dan disertai dengan teknologi cache. Keberadaan dua fitur itu membuat telegram lebih hemat dalam menyimpan data berupa teks, foto maupun video, yang tersimpan dalam histori percakapan dismartphone peserta didik. Ketika peserta didik tidak mengikuti pembelajaran, peserta didik tetap dapat mengikuti pembelajaran karena histori pembelajaran masih ada.

Dalam pembelajaran Bahasa Indonesia tidak hanya memahami video pembelajaran saja tetapi juga pembelajaran yang berbasis teks untuk memudahkan siswa dalam pembuatan artikel atau teks lainnya menggunakan tool telegraph. Fitur tersebut bermanfaat sekali ketika akan membuat artikel atau teks (pesan 
panjang) untuk memudahkan pengiriman dan penayangan (quick view) melalui chat atau publish.

Selain penggunaan tool telegraph untuk membuat artikel atau teks, dalam pembelajaran bahasa Indonesia juga menggunakan fitur bot yang dimiliki oleh telegram. Fungsi bot dapat memudahkan guru dalam melakukan banyak hal diantaranya quis bot atau poll bot dan ultimate poll bot. Quis bot atau poll bot digunakan dalam pembelajaran Bahasa Indonesia untuk mengetahui tingkat pemahaman siswa terhadap materi yang telah dipelajarinya. Para peserta didik bisa memulai kuis sesaat dan hasilnya pun dapat dilihat oleh guru dalam waktu yang relatif singkat. Selain quis bot yang digunakan dalam pembelajaran bahasa Indonesia, guru juga ingin mengetahui kehadiran peserta didiknya, oleh karena itu guru menggunakan Ultimate poll bot untuk mengetahui berapa persen peserta didik yang hadir ketika pembelajaran bahasa Indonesia.

Penggunaan teknologi berbasis internet membutuhkan akses internet agar aplikasi dapat digunakan. Peserta didik juga menggunakan laptop atau menggunakan gawai mereka agar bisa bergabung menggunakan aplikasi telegram. Untuk itu, setiap gawai pasti memiliki spesifikasi yang berbeda-beda. Dalam penggunaan alat-alat teknologi tersebut tentunya butuh akses internet. Pemanfaatan telegram memudahkan guru dan peserta didik dalam proses pembelajaran dari rumah. Meskipun tetap ada pertanyaan-pertanyaan dari peserta didik karena tetap belum dapat memahami apa yang disampaikan maksud gurunya. Beberapa guru selalu tanggap dan sabar dalam memberikan penjelasan kepada peserta didik. Pembelajaran daring ini merupakan tantangan baru untuk guru-guru dan peserta didik.

Menurut Astini (2020:15) pembelajaran daring menggunakan sistem pembelajaran melalui media internet atau media jaringan komputer yang bisa diakses kapanpun dan dimanapun guna menyampaikan bahan ajar kepada peserta didik. Dengan memanfaatkan telegram sebagai sarana pembelajaran daring lebih fleksibel dan diharapkan dapat mengembangkan potensi peserta didik. Hasil penelitian yang telah dilakukan mencakup siklus kesatu dan siklus kedua sesuai perencanaan yang telah dibuat sebelumnya. Hasil dari test mengidentifikasi nilai- 
nilai yang terkandung dalam teks cerita rakyat (hikayat) pada tahapakhir masingmasing siklus.

Pada siklus pertama, kegiatan belajar dilakukan dengan metode diskusi melalui model pembelajaran contextual teaching and learning (CTL) sesuai dengan rencana tindakan. Berdasarkan data hasil pengamatan mitra peneliti hasilnya menunjukkan bahwa peserta didik belum mampu beradaptasi dengan pola model ini, karena pada pembelajaran sebelumnya pola model ini sudah diperkenalkan. Namun, masih terdapat banyak kekurangannya sehingga pada tahap ini belum terlihat adanya peningkatan kemapuan dan hasil belajar peserta didik. Hal tersebut terlihat berdasarkan data hasil post-tes.

Tabel 1. DATA HASIL POST-TES SIKLUS IKKM : 75)

\begin{tabular}{|c|c|c|}
\hline No. & Nama & Keterangan \\
\hline 1. & Jumlah Peserta Didik & 29 \\
\hline 2. & Jumlah Peserta Didik Aktif & 6 \\
\hline 3. & Jumlah Peserta Didik Tidak Aktif & 23 \\
\hline 4. & Prosentase Keaktifan & $79 \%$ \\
\hline 5. & $\begin{array}{l}\text { Jumlah Peserta didik mampu mengidentifikasinilai- } \\
\text { nilai yang terkandung dalam teks cerita rakyat } \\
\text { (hikayat) }\end{array}$ & 6 \\
\hline 6. & $\begin{array}{l}\text { Jumlah Peserta didik belum } \quad \text { mampu } \\
\text { mengidentifikasi nilai-nilai yang terkandung } \\
\text { dalam teks cerita rakyat (hikayat) }\end{array}$ & 23 \\
\hline 7. & $\begin{array}{l}\text { Prosentase Kemampuan mengidentifikasi nilai-nilai } \\
\text { yang terkandung dalam teks cerita rakyat (hikayat) }\end{array}$ & $79 \%$ \\
\hline 8. & Jumlah Peserta Didik Tuntas & 12 \\
\hline 9. & Jumlah Peserta Didik Belum Tuntas & 17 \\
\hline 10. & Nilai Rata-rata & 64 \\
\hline 11. & Prosentase Kelulusan & $41 \%$ \\
\hline 12. & Prosentase Ketidaklulusan & $59 \%$ \\
\hline
\end{tabular}

Berdasarkan tabel 1, tingkat kemampuan peserta didik Kelas X Rekayasa Perangkat Lunak 1 SMK Negeri 1 Rembang dalam pembelajaran mata pelajaran Bahasa Indonesia pada materi mengidentifikasi nilai-nilai yang terkandung dalam teks cerita rakyat (hikayat), dengan model pembelajaran contextual teaching and 
learning (CTL) metode diskusi dengan jumlah peserta didik sebanyak 29 peserta didik, ternyata 23 peserta didik (79\%) dapat dinyatakan aktif dan mampu mengidentifikasi nilai-nilai yang terkandung dalam teks cerita rakyat (hikayat) dan sisanya 6 peserta didik (21\%) dinyatakan tidak aktif dan belum mampu mengidentifikasi nilai-nilai yang terkandung dalam teks cerita rakyat (hikayat). Pada post-tes (penilaian) ke-1, ternyata 12 peserta didik dapat dinyatakan Tuntas (41\%) karena nilai yang diperoleh telah sama atau melebihi KKM (Kriteria Ketuntasan Minimal) dan sisanya 17 peserta didik dinyatakan Belum Tuntas (59\%).

Berdasarkan hasil refleksi, yakni kegiatan diskusi antara penenliti dan mitra peneliti ditemukan 5 poin yang masih harus diperbaiki oleh peneliti (guru) yakni: (a) keterlibatan peserta didik dalam diskusi kelompok, disimpulkan sebagian besar masih kurang terlibat; (b) keterlibatan peserta didik dalam diskusi kelas, disimpulkan sebagian besar masih kurang terlibat; (c) keinginan untuk mendapatkan hasil yang terbaik terutama dalam diskusi kelompok, disimpulkan masih kurang memiliki keinginan tersebut; (d) timbulnya rasa keingintahuan dan keberanian peserta didik, disimpulkan masih kurang; (e) kemauan peserta didik menyediakan alat-alat atau sumber/bahan pelajaran yang dibutuhkan, juga dianggap masih kurang. Selain ke- 5 poin tersebut, hal lain yang juga perlu mendapat perhatian adalah masih kurangnya keseriusan peserta didik dan keaktifan peserta didik dalam mengikuti pelajaran.

Hasil diskusi antara peneliti dan mitra peneliti, diperoleh kesepahaman sebagai berikut: (1) Budaya baca dikalangan peserta didik masih rendah, oleh karena itu diusahakan agar contoh teks yang ditampilkan adalah video animasi yang tidak terlalu sulit dipahami peserta didik; (2) Pola model contextual teaching and learning (CTL) dengan metode diskusi sebaiknya lebih banyak menggunakan metode yang lebih banyak menuntut tanggung jawab individu dan menggunakan platform tambahan selain telegram berupa google meet; (3) Langkah-langkah pengerjaan tugas baik tugas individu maupun kelompok harus dijelaskan secara terperinci oleh guru; (4) Guru harus memberitahukan atau menekanankan kepada peserta didik tentang adanya penilaian proses kegiatan belajar. 
Pada siklus kedua, kegiatan belajar dilakukan dengan metode diskusi melalui model pembelajaran contextual teaching and learning (CTL) sesuai dengan rencana tindakan. Berdasarkan data hasil pengamatan mitra peneliti hasilnya menunjukkan bahwa peserta didik sudah mampu beradaptasi dengan pola model ini, karena pada pelajaran sebelumnya pola model ini sudah diperkenalkan. Sudah terlihat kelebihannya yaitu pada tahap ini terlihat adanya peningkatan kemapuan dan hasil belajar peserta didik. Hal tersebut terlihat berdasarkan data hasil post-tes pada tabel 2 .

Tabel 2. DATA HASIL POST-TES SIKLUS II(KKM : 75)

\begin{tabular}{|c|c|c|}
\hline No. & Nama & Keterangan \\
\hline 1. & Jumlah Peserta Didik & 29 \\
\hline 2. & Jumlah Peserta Didik Aktif & 26 \\
\hline 3. & Jumlah Peserta Didik Tidak Aktif & 3 \\
\hline 4. & Prosentase Keaktifan & $90 \%$ \\
\hline 5. & $\begin{array}{l}\text { Jumlah Peserta didik mampu mengidentifikasi } \\
\text { nilai-nilai yang terkandung dalam teks cerita } \\
\text { rakyat (hikayat) }\end{array}$ & 26 \\
\hline 6. & 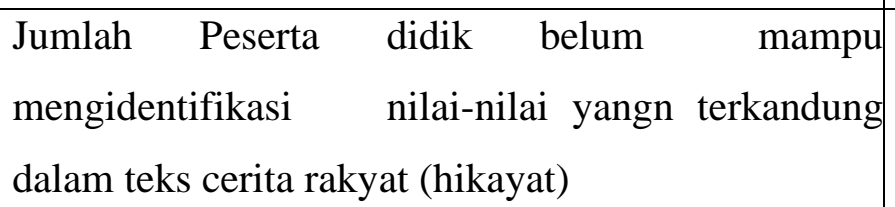 & 3 \\
\hline 7. & $\begin{array}{l}\text { Prosentase Kemampuan mengidentifikasi nilai- } \\
\text { nilai yang terkandung dalam teks cerita rakyat } \\
\text { (hikayat) }\end{array}$ & $90 \%$ \\
\hline 8. & Jumlah Peserta Didik Tuntas & 19 \\
\hline 9. & Jumlah Peserta Didik Belum Tuntas & 10 \\
\hline 10. & Nilai Rata-rata & 76,6 \\
\hline 11. & Prosentase Kelulusan & $66 \%$ \\
\hline 12. & Prosentase Ketidaklulusan & $34 \%$ \\
\hline
\end{tabular}

Berdasarkan data tersebut, tingkat kemampuan peserta didik Kelas X Rekayasa Perangkat Lunak 1 SMK Negeri 1 Rembang dalam pembelajaran mata pelajaran Bahasa Indonesia pada materi mengidentifikasi nilai-nilai yang 
terkandung dalam teks cerita rakyat (hikayat), dengan model pembelajaran contextual teaching and learning (CTL) metode diskusi dengan jumlah peserta didik sebanyak 29 peserta didik, ternyata 26 peserta didik (90\%) dapat dinyatakan aktif dan mampu mengidentifikasi nilai-nilai yang terkandung dalam teks cerita rakyat (hikayat) dan sisanya 3 peserta didik (10\%) dinyatakan tidak aktif dan belum mampu mengidentifikasi nilai-nilai yang terkandung dalam teks cerita rakyat (hikayat). Pada post-tes (penilaian) ke-2, ternyata 19 peserta didik dapat dinyatakan Tuntas (66\%) karena nilai yang diperoleh telah sama atau melebihi KKM (Kriteria Ketuntasan Minimal) dan sisanya 10 peserta didik dinyatakan Belum Tuntas (34\%).

Berdasarkan hasil refleksi, yakni kegiatan diskusi antara penenliti dan mitra peneliti ditemukan 5 poin yang masih harus diperbaiki oleh peneliti (guru) yakni: (a) keterlibatan peserta didik dalam diskusi kelompok, yakni disimpulkan sebagian besar sudah terlibat; (b) keterlibatan peserta didik dalam diskusi kelas, yakni disimpulkan sebagian besar sudah terlibat; (c) keinginan untuk mendapatkan hasil yang terbaik terutama dalam diskusi kelompok, yakni disimpulkan sudah memiliki keinginan tersebut; (d) timbulnya rasa keingintahuan dan keberanian peserta didik, disimpulkan sudah meningkat; (e) kemauan peserta didik menyediakan alat-alat atau sumber/bahan pelajaran yang dibutuhkan, yakni juga dianggap sudah meningkat. Selain ke-5 poin tersebut, hal lain yang juga perlu mendapat perhatian adalah masih minimnya kuota dan signal yang dimiliki peserta didik dalam mengikuti pelajaran.

Hasil tersebut dapat disimpulkan bahwa pembelajaran menggunakan pembelajaran contextual teaching and learning (CTL) dapat mengatasi masalah peserta didik dalam mengidentifikasi nilai-nilai yang terkandung dalam teks cerita rakyat (hikayat) dan dapat membuat peserta didik berpartisifasi aktif dalam proses pembelajaran. Hal ini membuktikan bahwa implementasi tindakan pada siklus II mendapat respon yang positif dan siklus II merupakan penutup penelitian tindakan kelas yang telah dilaksanakan.

Pada siklus ketiga, kegiatan belajar dilakukan dengan metode diskusi melalui model pembelajaran contextual teaching and learning (CTL) sesuai dengan rencana tindakan menggunakan platform telegram dan google meet. 
Berdasarkan data hasil pengamatan mitra peneliti hasilnya menunjukkan bahwa peserta didik sudah mampu beradaptasi dengan pola model ini, karena pada pelajaran sebelumnya pola model ini sudah diperkenalkan. Sudah terlihat kelebihannya yaitu pada tahap ini terlihat adanya peningkatan kemapuan dan hasil belajar peserta didik. Hal tersebut terlihat berdasarkan data hasil post-tes pada tabel 3 .

Tabel 3. DATA HASIL POST-TES SIKLUS III (KKM : 75)

\begin{tabular}{|c|c|c|}
\hline No. & Nama & Keterangan \\
\hline 1. & Jumlah Peserta Didik & 29 \\
\hline 2. & Jumlah Peserta Didik Aktif & 27 \\
\hline 3. & Jumlah Peserta Didik Tidak Aktif & 2 \\
\hline 4. & Prosentase Keaktifan & $93 \%$ \\
\hline 5. & $\begin{array}{l}\text { Jumlah Peserta didik mampu mengidentifikasi } \\
\text { nilai-nilai yang terkandung dalam teks cerita } \\
\text { rakyat (hikayat) }\end{array}$ & 27 \\
\hline 6. & $\begin{array}{l}\text { Jumlah Peserta didik belum mampu } \\
\text { mengidentifikasi nilai-nilai yang terkandung } \\
\text { dalam teks cerita rakyat (hikayat) }\end{array}$ & 2 \\
\hline 7. & $\begin{array}{l}\text { Prosentase Kemampuan mengidentifikasi nilai- } \\
\text { nilai yang terkandung dalam teks cerita rakyat } \\
\text { (hikayat) }\end{array}$ & $93 \%$ \\
\hline 8. & Jumlah Peserta Didik Tuntas & 22 \\
\hline 9. & Jumlah Peserta Didik Belum Tuntas & 7 \\
\hline 10. & Nilai Rata-rata & 76,9 \\
\hline 11. & Prosentase Kelulusan & $76 \%$ \\
\hline 12. & Prosentase Ketidaklulusan & $24 \%$ \\
\hline
\end{tabular}

Berdasarkan data tersebut, tingkat kemampuan peserta didik Kelas X Rekayasa Perangkat Lunak 1 SMK Negeri 1 Rembang dalam pembelajaran mata pelajaran Bahasa Indonesia pada materi mengidentifikasi nilai-nilai yang terkandung dalam teks cerita rakyat (hikayat), dengan model pembelajaran contextual teaching and learning (CTL) metode diskusi dengan jumlah peserta 
didik sebanyak 29 peserta didik, ternyata 27 peserta didik (93\%) dapat dinyatakan aktif dan mampu mengidentifikasi nilai-nilai yang terkandung dalam teks cerita rakyat (hikayat) dan sisanya 2 peserta didik (7\%) dinyatakan tidak aktif dan belum mampu mengidentifikasi nilai-nilai yang terkandung dalam teks cerita rakyat (hikayat). Pada post-tes (penilaian) ke-3, ternyata 22 peserta didik dapat dinyatakan Tuntas (76\%) karena nilai yang diperoleh telah sama atau melebihi KKM (Kriteria Ketuntasan Minimal) dan sisanya 7 peserta didik dinyatakan Belum Tuntas 24\%).

Berdasarkan hasil refleksi, yakni kegiatan diskusi antara penenliti dan mitra peneliti ditemukan 5 poin yang masih harus diperbaiki oleh peneliti (guru) yakni: (a) keterlibatan peserta didik dalam diskusi kelompok, yakni disimpulkan sebagian besar sudah terlibat; (b) keterlibatan peserta didik dalam diskusi kelas, yakni disimpulkan sebagian besar sudah terlibat; (c) keinginan untuk mendapatkan hasil yang terbaik terutama dalam diskusi kelompok, yakni disimpulkan sudah memiliki keinginan tersebut; (d) timbulnya rasa keingintahuan dan keberanian peserta didik, disimpulkan sudah meningkat; (e) kemauan peserta didik menyediakan alat-alat atau sumber/bahan pelajaran yang dibutuhkan, yakni juga dianggap sudah meningkat. Selain ke-5 poin tersebut, hal lain yang juga perlu mendapat perhatian adalah masih minimnya kuota dan signal yang dimiliki peserta didik dalam mengikuti pelajaran.

Kesimpulan bahwa pembelajaran menggunakan pembelajaran contextual teaching and learning (CTL) dapat mengatasi masalah peserta didik dalam mengidentifikasi nilai-nilai yang terkandung dalam teks cerita rakyat (hikayat) dan dapat membuat peserta didik berpartisifasi aktif dalam proses pembelajaran. Hal ini membuktikan bahwa implementasi tindakan pada siklus III mendapat respon yang positif dan siklus III ini merupakan penutup penelitian tindakan kelas yang telah dilaksanakan.

\section{SIMPULAN}

Berdasarkan hasil penelitian dan pembahasan yang dilakukan pada penelitiandi atas, disimpulkan bahwa

1) Penerapan media pembelajaran telegram dalam teks hikayat di SMKN 1

Rembang Purbalingga sangat berpengaruh terhadap proses pembelajaran 
Bahasa Indonesia. Peserta didik merasa proses kegiatan pembelajaran secara tatap muka atau berada di kelas seperti biasanya dianggap lebih optimal dan penyampaian materi yang diberikan oleh guru jauh lebih cepat dipahami. Guru yang sebagai motivator sangat memiliki peran penting saat memanfaatkan aplikasi telegram sehingga peserta didik tidak menjadi bosan dan pembelajaran menjadi lebih efektif dan menarik. disamping itu pemanfaatan telegram juga bisa menjadi tolak ukur perkembangan pendidikan.

2) Penggunaan model contextual teaching and learning (CTL) dapat meningkatan keaktifan peserta didik kelas X SMK Negeri 1 Rembang Purbalingga dalam mengidentifikasi nilai-nilai yang terkandung dalam teks cerita rakyat (hikayat). Hal tersebut dapat dibuktikan melalui prosentase keaktifan peserta didik dalam pembelajaran pada Siklus I hanya $79 \%$ dan meningkat pada Siklus III menjadi 93\%. Penggunaan model contextual teaching and learning (CTL) dapat meningkatan pemahaman peserta didik kelas X SMK Negeri 1 Rembang Purbalingga dalam mengidentifikasi nilainilai yang terkandung dalam teks cerita rakyat (hikayat). Hal tersebut dapat dibuktikan melalui prosentase kemampuan peserta didik dalam mengidentifikasi nilai-nilai yang terkandung dalam teks cerita rakyat (hikayat) pada Siklus I hanya 79\% dan meningkat pada Siklus III menjadi 93\%. Penggunaan model contextual teaching and learning (CTL) dapat meningkatan hasil belajar peserta didik kelas X SMK Negeri 1 Rembang Purbalingga dalam mengidentifikasi nilai-nilai yang terkandung dalam teks cerita rakyat (hikayat). Hal tersebut dapat dibuktikan melalui prosentase kelulusan peserta didik pada Siklus I hanya $41 \%$ dan meningkat pada Siklus III menjadi 76\%.Diharapkan sebisa mungkin siswa fokus dalam memahami materi yang disampaikan oleh guru. Jika ada kesalahan teknis seperti jaringan yang tidak stabil atau perangkat yang mati secara tiba-tiba, usahakan jangan panik dan tetap rileks.

Keberhasilan sistem pembelajaran berbasis online dipengaruhi oleh beberapa komponen baik itu peserta didik, guru, sumber materi atau bahan ajar, maupun teknologi informasi. Jika pembelajaran berbasis online diterapkan dalam 
jangka panjang tanpa diselingi dengan model pembelajaran lain tentunya dapat menimbulkan rasa jenuh. Diperlukan model pembelajaran daring yang lebih variatif sebagai alternatif yang dapat digunakan dimasa mendatang agar pembelajaran tetap menarik sehingga tujuan dari pendidikan secara umum dapat tercapai. Pembelajaran berbasis online dinilai tepat untuk diterapkan pada masa pandemi Covid-19. Diharapkan pandemi Covid-19 ini segera berlalu agar peserta didik dan masyarakatluas dapat menjalankan aktivitasnya seperti sedia kala.

\section{DAFTAR RUJUKAN}

Ariskisaputri. 2019. Pengertian, fungsi dan cara menggunakan bot telegram. https://www.bukugue.com/apa-itu-bot-telegram/

Astini, Suni. 2020. Tantangan Dan Peluang Pemanfaatan Teknologi Informasi Dalam Pembelajaran Online Masa Covid-19. Jurnal Ilmu Pendidikan Vol. 3. http://jayapanguspress.penerbit.org/index.php/cetta/article/view/452

Badarman. 2010. "Karakteristik Peneltian Tindakan Kelas (PTK)” dalam Jurnal Diklat Keagamaan Edisi 13 (hlm. 92). Surabaya: Balai Diklat Keagamaan.

Jani. 2009. "Penelitian Tindakan Kelas dan Manfaatnya Bagi Peningkatan Efektivitas Pembelajaran" dalam Jurnal Ta'alum Volume 19 Nomor 1 Juni 2009 (hlm. 16-22). Tulungagung: STAIN Tulungagung.

Juniartini. 2020. Pemanfaatan Aplikasi Google Meet dalam keterampilan

Menyimak dan Berbicara untuk Pembelajaran Bahasa pada Masa Pandemi

Covid-19. Jurnal Ilmu Pendidikan Vol.9. 2

Kelas Pintar. 2019. Macam-macam Nilai pada Buku Fiksi dan Nonfiksi. Diperoleh 7 Oktober 2020, dari https://www.kelaspintar.id/blog/tipspintar/macam-macam-nilai-pada-buku-fiksi-dan-nonfiksi-2167/

Pendidikan.co.id. 2020. Pengertian Hikayat dan Contohnya. Diperoleh 7 Oktober 2020, dari https://pendidikan.co.id/hikayat/

Purba, Ika Rosenta. 2010. "Pengajaran dan Pembelajaran Kontekstual Adalah Salah Satu Pendekatan dan Model Pembelajaran Efektif” dalam Jurnal. Habonaron Dobona Edisi 1 Maret 2020 (hlm. 30). Sumatera Utara: Universitas Simalungun (USI). 
Purnomo, Dwi. 2008. "Pembelajaran Kontekstual Berpandu Kontruktivis dan Pelaksanaannya di Kelas" dalam Jurnal Paradigma Tahun XIII Nomor 26, Juli-Desember 2008 (hlm. 318-321). Malang: IKIP Budi Utomo Malang. Wahyuni, Sri Indra. 2020. Nilai Sosial dalam Cerpen "Titik dikala Senja” dalam Antologi Cerpen Penjara. Jurnal Ilmu Pendidikan Vol 9. 2. 